\title{
Effects of Some Phenolic Compounds on Soybean Seed Germination and on Seed-borne Fungi
}

\author{
Flávia Tavares Colpas ${ }^{1}$, Elizabeth Orika Ono ${ }^{2 *}$, João Domingos Rodrigues ${ }^{2}$ and José \\ Raimundo de Souza Passos ${ }^{3}$ \\ ${ }^{1}$ Instituto de Biociências; UNESP; Botucatu - SP - Brazil. ${ }^{2}$ Departamento de Botânica; Instituto de Biociências; \\ UNESP; C. P. 510; CEP 18610-000; Botucatu - SP - Brazil. ${ }^{3}$ Departamento de Bioestatística; Instituto de \\ Biociências; UNESP; Botucatu - SP - Brazil
}

\begin{abstract}
Studies were carried out on the effects of coumarin, ferulic acid and naringenin on soybean seed germination and on the growth of seed-borne fungi at concentrations of 50 and $100 \mathrm{mg} . \mathrm{L}^{-1}$. The compounds showed good inhibition of seed germination, especially at $50 \mathrm{mg} . \mathrm{L}^{-1}$, but little fungistatic activity. Possible mechanisms of action are discussed.
\end{abstract}

Key words: Glycine max, soybean, phenolics, coumarin, ferulic acid, naringenin

\section{INTRODUCTION}

A major difference between plants and animals is the ability of plants to accumulate a wide variety of low molecular weight constituents, resulting from long metabolic pathways: the secondary metabolites (Harborne, 1997). Among these are terpenes, nitrogen-containing compounds and phenolics, which are synthesized from AcetylCoA, aminoacids and schikimic and malonic acids, respectively (Taiz and Zeiger, 1998). The schikimic acid pathway was added to the acetate path early in Angiosperm flora, diversifying gradually and then declining again in modern orders (Gottlieb et al., 1996). Also, the type of phytoalexins produced is likely to be related to existing preinfectional agents present in a given family (Harborne, 1999).
While terpenes and nitrogen-containing compounds are recognized mostly in antiherbivore interations, phenolic compounds are also related to defense against pathogens, mechanical support, attraction of pollinators and fruit dispersers, absorption of harmful ultraviolet radiation and in reducing the growth of competing plants (Taiz and Zeiger, 1998).

Besides competition for moisture, light and soil nutrients, plants have developed chemical defense mechanisms (allelopathy), through the use of simple-structured, low molecular weight secondary metabolites, whose effectiveness depend on the speed with which soil microorganisms are able to detoxify and metabolize them (Harborne, 1993). Chemical interactions involving plants and micro-organisms may be compatible or incompatible and begin with elicitor-mediated genetic recognition, which triggers signal amplification and gene activation,

\footnotetext{
* Author for correspondence
} 
and culminate in the activation of defense mechanisms, such as hypersensitive response, systemic acquired resistence (Cordeiro and Sá, 2000) and phytoalexin induction. This latter can be also triggered by stress conditions, intense cold, ultraviolet radiation, tissue injury, osmotic stress, abiotic agents (fungicides, metallic ions, fosfite, ethylene and glutation) and biotic agents (Maestro-Durán et al., 1993). The interaction with organic matter is important in establishing phenolics inhibitory concentrations, since at field conditions these are lower than those used in laboratory (Blum, 1996). Soil nutritional state, such as nitrogen availability, influences phenolics mechanism of action (Klein and Blum, 1990) and their constitutive levels in plants (Stout et al., 1998).

In general, phenolics have the property of altering mitochondria and chloroplasts membranes, hindering the energy transfer necessary to ion transport, as observed in spinach (Moreland and Novitzky, 1987). Coumarins seem to inhibit mitosis alike colchicine, showing antimicrotubule effects (Cornman, 1946). For phenolic acids, polyphenols (but not monophenols) seem to increase IAA-mediated growth by inhibiting IAA oxidative decarboxilation (Tomaszewski and Thimann, 1966). This can be extended for flavonoids. Antifungal flavonoids (pterocarpans) seem to have their activity related to the molecule's non-planarity and to the presence of small oxygen-containing substituents in specific positions (Perrin and Cruickshank, 1969). Other factors, such as the presence of assymetric carbons and compound solubility as well as other physiochemical properties or the involvement of different receptors must be considered (VanEtten, 1976).

Phenolic compounds are important in the formation of vegetational patterns and ecological succession processes, showing many applications on forestry and agriculture (Rice, 1987). Laboratory bioassays are of great importance on allelopathy study (Inderjit and Dakshini, 1995), seed germination being a usual parameter (Rice, 1984). There are many facets to be considered in the study of allelopathic interactions (Harborne, 1993), as well as in the understanding of other plant defense mechanisms. The objective of this paper was to test the allelopathic effect coumarin, ferulic acid and naringenin on soybean seed germination and their fungistatic activity on seedborne fungi.

\section{MATERIALS AND METHODS}

Plant material. Soybean (Glycine max L. Merrill) seeds, cv. BRS-155 and IAC-19, were acquired from Departamento de Agricultura, Faculdade de Ciências Agronômicas - UNESP.

Phenolics and concentrations. The compounds used were coumarin (RP), and ferulic acid and naringenin (Sigma) at concentrations of 50 and $100 \mathrm{mg} . \mathrm{L}^{-1}$.

Two experiments were set up: (1) a seed germination test and (2) a seed health test.

Germination test. BRS-155 seeds were prepared according to 'Regras para Análise de Sementes' (Rules for Seed Analysis) (Brasil, 1992). Three sheets of filter paper substrate were embedded with the testing-solutions or distilled water (control) (2.5 times v/w). Fifty seeds were placed between sheets and rolled up. Each treatment scroll was isolated with transparent plastic bag and maintained in FANEM $^{\circledR}$ germinator under constant white light and $25^{\circ}$ temperature for 8 days. Daily counts of germinated seeds (radicle $>2 \mathrm{~mm}$ ) were made.

Health test. For this the filter paper method was used (Lucca Filho, 1987). Seeds were embbeded in the testing-solutions or distilled water (control) for 8 hours and placed in gerboxes (20/box) containing 3 sheets of filter paper moistened with distilled water. Seeds were incubated in FANEM $^{\circledR}$ germinator at $20 \pm 2^{\circ} \mathrm{C}$ and intermittent light regime (12-hour light/12-hour dark). After 7 days, seeds were observed under stereoscopic microscope to verify the occurrence of the following fungal species: Aspergillus spp., Cercospora kikuchii, Cercospora sojina, Colletotrichum dematium, Fusarium spp., Macrophomina phaseolina, Penicillium spp. Phomopsis phaseoli and Rhizoctonia solani.

Statistical analysis. Two hundred seeds were used for each treatment, being 4 repetitions of 50 seeds in the germination test and 10 repetitions of 20 in the health test. Data were expressed as the mean of all repetitions. Germination percentage data were analyzed by using the analysis of variance and the means compared by Tukey's teste $(\mathrm{P}=$ 
0.05). Poisson model was used for statistically significant differences $(\mathrm{p} \leq 0.05)$.

\section{RESULTS AND DISCUSSION}

Seed germination results (Fig. 1 and Table 1) showed a highly inhibitory activity of the tested compounds. According to germination percentage, three groups were observed: (1) control $\left(\mathrm{T}_{7}\right)$, with $94.5 \%$, (2) ferulic acid and coumarin at $100 \mathrm{ppm}$ $\left(\mathrm{T}_{2}\right.$ and $\left.\mathrm{T}_{4}\right)$, with around $30 \%$, and (3) naringenin at both concentrations, ferulic acid and coumarin at $50 \mathrm{ppm}\left(\mathrm{T}_{1}, \mathrm{~T}_{3}, \mathrm{~T}_{5}\right.$ and $\left.\mathrm{T}_{6}\right)$, with less than $4 \%$.

Naringenin at $50 \mathrm{ppm}$ treatment $\left(\mathrm{T}_{5}\right)$ showed total inhibition. Seed germination was most inhibited at the 50 ppm concentration.

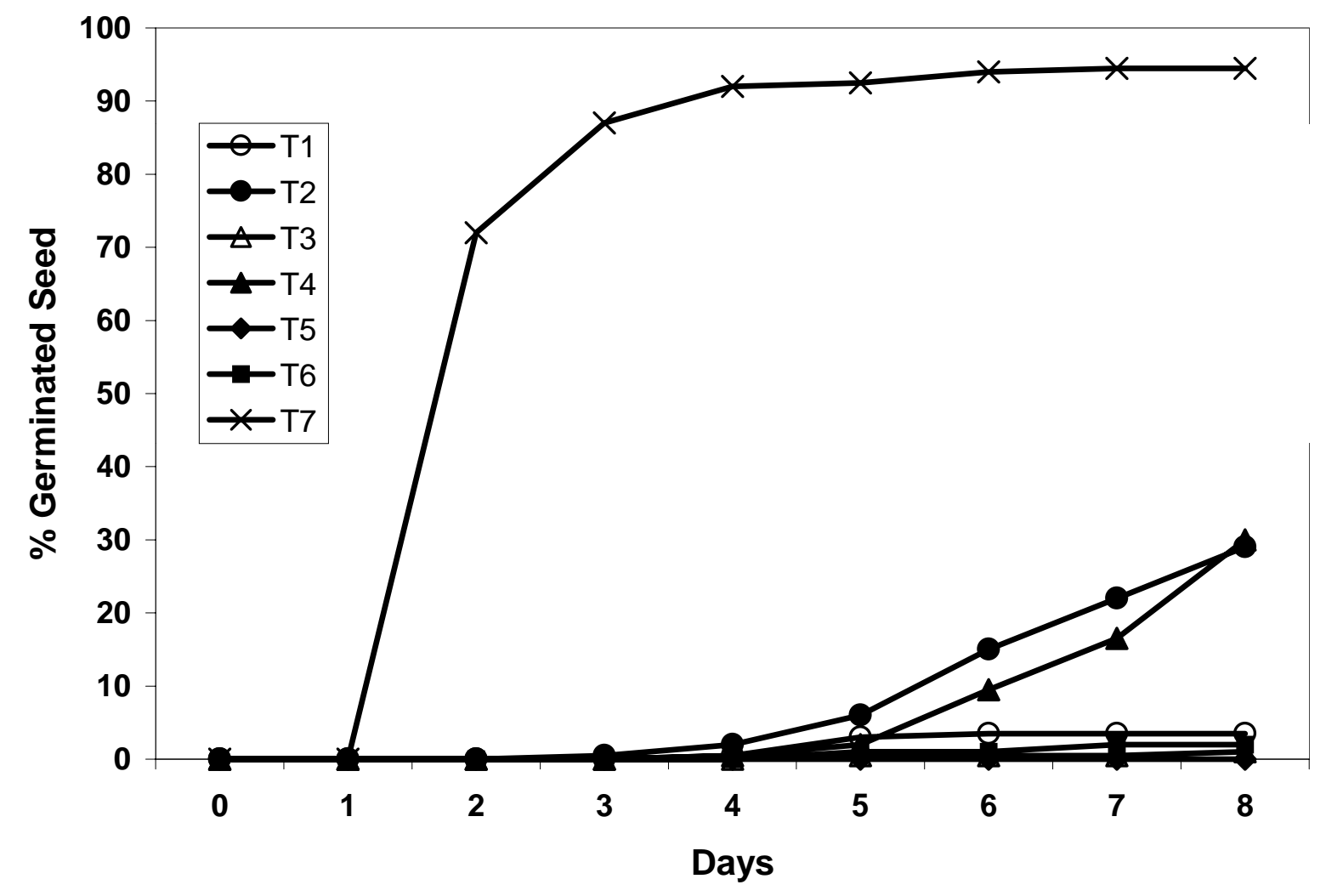

Figure 1 - Germination percentage of phenolic-treated BRS-155 seeds during the 8-day experiment, under constant white light and $25^{\circ}$ temp. $\left(\mathrm{T}_{1}=\right.$ ferulic acid $50 \mathrm{ppm}, \mathrm{T}_{2}=$ ferulic acid $100 \mathrm{ppm}, \mathrm{T}_{3}=$ coumarin 50 ppm, $\mathrm{T}_{4}=$ coumarin $100 \mathrm{ppm}, \mathrm{T}_{5}=$ naringenin $50 \mathrm{ppm}, \mathrm{T}_{6}=$ naringenin $100 \mathrm{ppm}, \mathrm{T}_{7}=$ control$)$.

Competitive chemical effects not only operated on seed germination, but on all aspects of growth (Reynolds, 1977). Inhibition by ferulic acid and coumarin on lettuce seed germination were observed at concentrations of $10^{-3}-10^{-5} \mathrm{M}$ (Williams and Hoagland, 1982; Li et al., 1993). Coumarin at $100 \mathrm{ppm}$ also inhibited lettuce germination and reduced radicle elongation at lower concentrations (Yamamoto and Fujii, 1997). Ferulic acid also showed inhibition of cucumber seedling growth at concentrations of $0.125-0.8$ mM (Blum and Rebbeck, 1989; Booker et al., 1992; Lehman et al., 1994) and at $10 \mu \mathrm{g} / \mathrm{g}$ soil (Blum, 1996).

In our experiment, primary roots reached a maximum of $1-2 \mathrm{~cm}$ in ferulic acid and coumarin treatments and about $0.5 \mathrm{~cm}$ in naringenin treatments. In the first treatments, stunted roots with necrotic tips were observed (control showed normal seedling development). This morphology 
suggested a possible common mechanism of action for ferulic acid and coumarin.

Table 1 - Analysis of variance of germination percentage of phenolic-treated BRS-155 seeds, under constant white light and $25^{\circ} \mathrm{C}$ temperature.

\begin{tabular}{lc}
\hline Treatment & $\%$ germinated seed $^{1}$ \\
\hline Ferulic acid 50ppm & $3.5 \mathrm{c}$ \\
Ferulic acid 100ppm & $29 \mathrm{~b}$ \\
Coumarin 50ppm & $1 \mathrm{c}$ \\
Coumarin 100ppm & $30 \mathrm{~b}$ \\
Naringenin 50ppm & $0 \mathrm{c}$ \\
Naringenin 100ppm & $2 \mathrm{c}$ \\
Control & $94.5 \mathrm{a}$ \\
$\mathrm{F}$ & $243.5^{*}$ \\
C.V. $(\%)$ & 13.47 \\
\hline
\end{tabular}

${ }^{\mathrm{T}}$ Means, followed by same letter not statistically differ by Tukey's test at $5 \%$.

These compounds seemed to act alike mitosis disrupter herbicides on microtubules. Microtubules were responsible for setting the plane for cell division and cellulose deposition (Vaughn and Lehnen, 1991). Wall deposition accounted for a cylindrical cell shape (Green, 1962), which is responsible for elongation. The effect of the herbicide 1-(4-cloro- $\alpha-(2,2,3,3,3-$ pentafluoropropoxi)- $m$-toli)-5-fenil $H, 2,4$,-triazole- 3-carboxamide on watercress roots resulted in the known 'club morphology', which cell elongation (Hoffman and Vaughn, 1996). Even with little information on flavonoids activity on seed germination, our results suggested a greater activity of naringenin compared with the other compounds. It was not possible to observe naringenin effect on root morphology at 50 or 100 ppm, but roots showed the same morphology as other treatments when lower concentrations were used. The higher effectiveness of naringenin could be attributed to the fact that flavonoids accounted for $80-90 \%$ of seed composition (Graham, 1991), which implicated the existence of specialized metabolism on compounds of this nature.

Seed health results (Table 2) showed that the occurence of fungal species varied immensally depending on the cultivar, compound and concentration used. Colletotrichum dematium and Penicillium sp. (both cultivars) and Phomopsis phaseoli (cv. IAC-19) did not show statistical differences compared to the control. It was observed that mycelial growth was inhibited in cv. IAC-19 and stimulation in cv. BRS-155 for Aspergillus spp., Cladosporium spp., and in both cultivars for Fusarium spp..

Table 2 - Percentage of fungal occurrence in phenolic-treated seeds, cv. BRS-155 and IAC-19, after the 7-day incubation under 12-hr. ligth/12-hr. dark regime and $20^{\circ} \mathrm{C}$ temp. $\left(\mathrm{T}_{1}=\right.$ ferulic acid $50 \mathrm{ppm}, \mathrm{T}_{2}=$ ferulic acid 100 ppm, $\mathrm{T}_{3}=$ coumarin $50 \mathrm{ppm}, \mathrm{T}_{4}=$ coumarin $100 \mathrm{ppm}, \mathrm{T}_{5}=$ naringenin $50 \mathrm{ppm}, \mathrm{T}_{6}=$ naringenin $100 \mathrm{ppm}, \mathrm{T}_{7}=$ control).

\begin{tabular}{|c|c|c|c|c|c|c|c|c|c|c|c|c|c|c|}
\hline & \multicolumn{7}{|c|}{$B R S-155$} & \multicolumn{7}{|c|}{$I A C-19$} \\
\hline & $\mathrm{T} 1$ & T 2 & T 3 & $\mathrm{~T} 4$ & T 5 & T 6 & T 7 & T 1 & T 2 & T 3 & $\mathrm{~T} 4$ & T 5 & T 6 & $\mathrm{~T}$ \\
\hline $\operatorname{Asp}^{(1)}$ & 21,5 & 18 & 25,5 & $38^{*}$ & 25,5 & $39 *$ & 22,5 & 7 & $6^{*}$ & 7 & $4 *$ & $3 *$ & 6,5 & 7, \\
\hline $\mathrm{Cla}^{(2)}$ & 22,5 & 22,5 & $40 *$ & 30,5 & 22,5 & 22,5 & 28 & $6^{*}$ & 11 & $5^{*}$ & $5,5 *$ & $\begin{array}{c}7,5 \\
*\end{array}$ & $\begin{array}{r}5,5 \\
*\end{array}$ & $\begin{array}{l}1 \\
6\end{array}$ \\
\hline $\mathrm{Col}^{(3)}$ & 1 & 5,5 & 1 & 4,5 & 1 & 1,5 & 2 & - & 0,5 & - & - & - & - & - \\
\hline $\mathrm{Fus}^{(4)}$ & 14 & 8,5 & 13,5 & 14 & $7 *$ & 20 & 10 & 16 & 13 & 8 & $5 *$ & $\begin{array}{r}11, \\
5\end{array}$ & 11 & $\begin{array}{l}1 \\
1\end{array}$ \\
\hline $\operatorname{Pen}^{(5)}$ & - & 4 & - & 0,5 & 2,5 & 0,5 & 3,5 & 0,5 & 0,5 & - & - & - & - & - \\
\hline $\mathrm{Pho}^{(6)}$ & - & - & - & - & - & - & - & 6 & 2 & - & 0,5 & - & 0,5 & 2 \\
\hline
\end{tabular}

* significant in qui-square test $(\mathrm{p} \leq 0.05)$

${ }^{(1)}$ Aspergillus spp.; ${ }^{(2)}$ Cladosporium spp.; ${ }^{(3)}$ Colletotrichum dematium; ${ }^{(4)}$ Fusarium spp.; ${ }^{(5)}$ Penicillium spp.; ${ }^{(6)}$ Phomopsis phaseoli.

It was shown that caffeic and vanillic acids inhibited the growth of Aspergillus flavus and A. parasiticus at $0.2 \mathrm{ppm}$ (Aziz et al., 1998).
Coumarins extracted from Amni majus were fungistatic to Phytophthora palmivora and Colletotrichum capsici at concentration of 250-2000 
ppm (Johri et al., 1992). Flavonoids are more effective in inhibiting fungal mycelial and spore growth. It was observed that naringenin inhibited Pyricularia spore germination at 70 ppm (Padmavati et al., 1997). This compound also caused a significant lag in Phytophthora sojae radial growth at concentrations of 60$120 \mu \mathrm{M}$ and total inhibition at $240 \mu \mathrm{M}$, even with 20-30\% being partially metabolized (RiveraVargas et al., 1993). In soybean, isoflavone aglycones genistein, daidzein and glycetein, and genistin, daidzin and glicetein glycosides showed good fungistatic activity at $0.005 \%$ (Naim et al., 1974).

Soybean-Phytophthora sojae interaction is one of the most studied relations in the investigation of plant defense responses. It was demonstrated that soybean cotyledons treated with a $P$. sojae wall glucan preparation (PWG) triggered glyceollin production in proximal cells and isoflavone conjugates in distal cells (Graham and Graham, 1996). Pathogen cell wall glucans may lead to the stimulation of other phenylpropanoid responses such as daidzein production, but also light may trigger genistein formation (Graham and Graham, 1996). In a minimal wound protocol, these authors were able to observe reponses led by protein elicitors originated from the injured soybean cotyledons, such as phenolic polymer deposition and glyceollin production. It was also showed that PWG enhanced these reponses. A non-specific glyceollin accumulation in soybean cotyledons and hypocotyls was induced by several carbohydrates isolated from Brewer's yeast, which showed comparable activity with a Phytophthora megasperma var. sojae elicitor (Hahn and Albersheim, 1978).

Isoflavones and isoflavonones do not show remarkable fungicidal activity, whereas the isoflavans are good inhibitors of mycelial growth. Growth of Aspergillus ochraceus was inhibited by some soybean and chickpea isoflavonoids, Penicillium digitatum and Fusarium culmorum were inhibited as stimulated depending on the concentration (Krämer et al., 1984). Aromatic compouds show an order of activity marked by hydroxilated rings (aldehydes>acids>alcohols), being also influenced by orto substitutions and methylation (Reynolds, 1977). The lateral chain of molecule assists penetration and perhaps attachment to the site of action in the pathogen, while the functional group brings the desorganization, resulting in inhibition. Compounds become more lipophilic by the methylation of hydroxil groups, which facilitates their passage through the pathogen citoplasmic membrane, and increase in the polarity of the inhibiting agent reduces its activity (Naim et al., 1974). Yet, flavonoid distribution pattern is organ specific and varies with developmental stages (Graham, 1991).

Lower and higher concentrations than those tested in this work were effective in controlling the growth of different plants and phytopathogens in several systems. But it seems to be confirmed the fact that the compound concentration is not limiting to inhibition, but contributes to it. Other factors must be considered. In seeds, it is important to consider size, integument permeability and the differential absorption of inhibitory compounds (Williams and Hoagland, 1982). Seed-borne fungi introduced in soil develop with its micro-organisms relations of antagonism, competition and parasitism and may alter host predisposition or cause cross protection (Menten and Bueno, 1987). Still, alike allelopathy, which results from the combined action of many allelochemicals (Rice, 1987), invading pathogens rarely encounter individual products in planta (Rivera-Vargas et al., 1993).

It is not simple to establish effective compoundconcentration relationships in the growth inhibition of competing plants or invading micro-organisms. Attention must be given to the factors contributing to such interactions. Biological chemical interactions are too complex phenomena to allow the annoucement of suffiently broad and satisfying plant defense mechanisms, but allows to understand stratagies used in specific situations.

\section{ACKNOWLEDGEMENTS}

We thank to FAPESP for finantial support, and to Dr. Maria Heloísa de Moraes for the training in the seed health test, to Dr. Kátia Schwan-Estrada and Maria Eugênia Cruz for the useful suggestions, and to all in Departamento de Agricultura (FCAUNESP) for suggestions and material donation. 


\section{RESUMO}

Os compostos fenólicos são metabólitos secundários importantes na ecologia vegetal, especialmente em relações alelopáticas e interações com microorganismos, sendo sintetizados principalmente através da via do ácido chiquímico. Neste trabalho, os efeitos de cumarina, ácido ferúlico e naringenina sobre a germinação de sementes de soja e sobre o crescimento de fungos contaminantes foram investigados, nas concentrações de 50 e 100 mg. $\mathrm{L}^{-1}$. A germinação das sementes e o crescimento dos fungos foram estudados através de método do rolo de papel e do método do papel de filtro, respectivamente. Os compostos mostraram alta inibição da germinação das sementes, principalmente a $50 \mathrm{mg} . \mathrm{L}^{-1}$, porém baixa atividade fungistática. Possíveis mecanismos de ação são discutidos.

\section{REFERENCES}

Aziz, N. H.; Farag, S. E.; Mousa, L. A. A. and AboZaid, M. A. (1998), Comparative antibacterial and antifungal effects of some phenolic compounds. Microbios, 93, 43-54.

Blum, U. (1996), Allelopathic interactions involving phenolic acids. J. Nematol., 28, 259-267.

Blum, U. (1998), Effects of microbial utilization of phenolic acids and their phenolic acid breakdown products on allelopathic interactions. J. Chem. Ecol., 24, 685-708.

Blum, U. and Rebbeck, J. (1989), Inhibition and recovery of cucumber roots given multiple treatments of ferulic acid in nutrient culture. J. Chem. Ecol., 15, 917-928.

Booker, F. L.; Blum, U. and Fiscus, E. L. (1992), Short-term effects of ferulic acid on ion uptake and water relations in cucumber seedlings. J. Exp. Bot., 43, 649-655.

Brasil. (1992), Regras para análise de sementes. Ministério da Agricultura, Brasília.

Cordeiro, M. C. R. and Sá, M. F. G. (2000), Interação planta-patógeno e o uso da biotecnologia na obtenção de plantas resistentes. Biotecnologia, 10.

Cornman, I. (1946), Alteration of mitosis by coumarin and parasorbic acid. Am.J.Bot., 33, 217.

Gotlieb, O. R.; Kaplan, M. A. C. and Borin, M. R. M. B. (1996), Evolução. In: Biodiversidade - um enfoque químico biológico. Rio de Janeiro : Editora UFRJ. pp. 81-109.
Graham, T. L. (1991), Flavonoid and isoflavonoid distribution in developing soybean seedling tissues and in seed and root exsudates. Plant Physiol., 95, 594-603.

Graham, T. L. and Graham, M.Y. (1996), Signaling in soybean phenylpropanoid responses. Plant Physiol., 110, 1123-1133.

Green, P.B. (1962), Mechanism for plant cellular morphogenesis. Science, 138, 1404-1405.

Hahan, M. G. and Albersheim, P. (1978), Host-pathogen interactions. XIV. Isolation and partial characterization of an elicitor from yeast extract. Plant Physiol., 62, 107-111.

Harborne, J. B. (1993), Introduction to ecological biochemistry. San Diego : Academic Press.

Harborne, J. B. (1997), Plant Secondary Metabolism. In: Crawley, M. J. (ed.). Plant Ecology. Oxford : Blackwell Science. pp. 132-155.

Harborne, J. B. (1999), The comparative biochemistry of phytoalexin induction in plants. Biochem. Syst. Ecol., 27, 335-367.

Hoffman, J. C. and Vaughn, K. C. (1996), Flupoxam induces classic club morphology but is not a mitotic disrupter herbicide. Pest. Biochem. Physiol., 55, 49-53.

Inderjit Dakshini, K. M. M. (1995), On laboratory bioassays in allelopathy. Bot. Rev., 61, 28-44.

Johri, J. K.; Banerji, R.; Chaurasia, R. S.; Misra, G.; Siddiqui, S. A.; Balasubrahmanyam, V. R. and Nigam, S. K. (1992), Coumarins as potent biocides against Colletotrichum capsici and Phytophthora palmivora. Fitoterapia, 63, 78-80.

Klein, K. and Blum, U. (1990), Effects of soil nitrogen level on ferulic acid inhibition of cucumber leaf expansion. J. Chem. Ecol., 16, 1371-1383.

Krämer, R. P.; Hindorf, H.; Jha, H. C.; Kallage, J. and Zilliken, F. (1984), Antifungal activity of soybean and chickpea isoflavones and their reduced derivatives. Phytochemistry, 23, 2203-2205.

Lehman, M. E.; Blum, U. and Gerig, T. M. (1994), Simultaneous effects of ferulic and $p 0$ coumaric acids on cucumber leaf expansion in split-root experiments. J. Chem. Ecol., 20, 1773-1782.

Li, H. H.; Inove, M.; Nishimura, H.; Mizutani, J. and Tsuzuki, E. (1993), Interactions of trans-cinnamic acid, its related phenolic allelochemicals, and abscisic acid in seedling growth and seed germination of lettuce. J. Chem. Ecol., 19, 1175-1787.

Lucca Filho, O. A. (1987), Metodologia dos testes de sanidade de sementes. In: Soave, J. and Wetzel, M. V. S. (ed.). Patologia de Sementes. Campinas : Fundação Cargill. pp. 276-298.

Maestro-Durán, R.; León, R. and Ruiz-Gutiérrez, V. (1993), Los compuestos fenólicos en la autodefensa de los vegetales. Grasas y Aceites de Sevilla, 44, 365-369.

Menten, J. O. M. and Bueno, J. T. (1987), Transmissão de patógenos pelas sementes. In: Soave, J. and Wetzel, M. V. S. (ed.). Patologia de Sementes. Campinas : Fundação Cargill. pp. 164-191. 
Moreland, D. E. and Novitzky, W. P. (1987), Effects of phenolic acids, coumarins, and flavonoids on isolated chloroplasts and mitochondria. In: Waller, G. R. (ed.). Allelochemicals: role in agriculture and forestry. Washington, DC : American Chemical Society. pp. 247-261.

Naim, M.; Gestetner, B.; Zilkah, S.; Birk, Y. and Bondi, A. (1974), Soybean isoflavones. Characterization, determination, and antifungal activity. J. Agr. F. Chem., 22, 806-810.

Padmavati, M.; Sakthivel, N.; Thara, K. V.; Reddy, A. R.; Padmavati, M. and Sakthivel, N. (1997), Differential sensitivity of rice pathogens to growth inhibition by flavonoids. Phytochemistry, 46, 499-502.

Perrin, D. R. and Cruickshank, I. A. M. (1969), The antifungal activity of pterocarpans towards Monilinia fructicola. Phytochemistry, 8, 971-978.

Reynolds, T. (1977), Comparative effects of aromatic compounds on inhibition of lettuce fruit germination. Ann. Bot., 42, 419-427.

Rice, E. L. (1984), Allelopathy. Orlando : Academic Press.

Rice, E. L. (1987), Allelopathy: an overview. In: Allelochemicals: role in agriculture and forestry, ed. G.R. Waller. American Chemical Society, Washington, DC, 8-22.

Rivera-Vargas, L. I.; Schmitthenner, A. F. and Graham, T. L. (1993), Soybean flavonoid effects on and metabolism by Phytophthora sojae. Phytochemistry, 32, 851-857.
Stout, M. J.; Brovont, R. A. and Duffey, S. S. (1998), Effect of nitrogen availability on expression of constitutive and inducible chemical defenses in tomato, Lycopersicon esculentum. J. Chem. Ecol., 24, 945-963.

Taiz, L. and Zeiger, E. (1998), Plant defense. In: Plant Physiology. Sinauer Associates, Sunderland, 347-376.

Van Etten, H. D. (1976), Antifungal activity of pterocarpans and other selected isoflavonoids. Phytochemistry, 15, 655-659.

Tomaszewski, M. and Thimann, K. V. (1966), Interactions of phenolic acids, metallic inos and chelating agents on auxIn:induced growth. Plant Physiol., 41, 1443-1454.

Vaughn, K. C. and Lehnen Jr., L. P. (1991), Mitotic disrupter herbicides. Weed Sci., 39, 450-457.

Williams, R. D. and Hoagland, R. E. (1982), The effects of naturally occurring phenolic compounds on seed germination. Weed Sci., 30, 206-212.

Yamamoto, Y. and Fujii, Y. (1997), Exudation of allelopathic compound from plant roots of sweet vernalgrass (Anthoxanthum odoratum). J. Weed Sci. Tech., 42, 31-35.
Received: November 13, 2001; Revised: April 25, 2002; Accepted: August 20, 2002. 